\title{
Optimizing conditions for enzymatic clarification of banana juice using response surface methodology (RSM).
}

\begin{abstract}
Raw banana juice is turbid, viscous and gray in colour. This work was initiated to optimize the enzymatic clarification process of banana juice using response surface methodology. Banana juice was treated with pectinase at various enzyme concentrations $(0.01-0.1 \%)$, temperatures $(30-50 \mathrm{C})$ and time $(30-120 \mathrm{~min})$ of treatment. The effect of these enzyme treatments on filterability, clarity, turbidity and viscosity of the juice were studied by employing a second order central composite design. The coefficient of determination, R2 values for filterability, clarity, turbidity and viscosity were greater than 0.900 . Statistical analysis showed that filterability, clarity, viscosity and turbidity were significantly $(\mathrm{p}<0.05)$ correlated to enzyme concentration, incubation temperature and incubation time. Enzyme concentration was the most important factor affecting the characteristics of the banana juice as it exerted a highly significant influence $(\mathrm{p}<0.01)$ on all the dependent variables. An increase in time and/or concentration of enzyme treatment was associated with an increase in filterability and clarity, and decrease in turbidity and viscosity. Based on response surface and contour plots, the optimum conditions for clarifying the banana juice were: $0.084 \%$ enzyme concentration, incubation temperature of $43.2 \mathrm{C}$ and incubation time of $80 \mathrm{~min}$.
\end{abstract}

Keyword: Banana juice, Enzymatic clarification, Response surface methodology 